\title{
Distribution of diazotrophic microorganisms and nifH gene expression in the Mekong River plume during intermonsoon
}

\author{
Deniz Bombar ${ }^{1,4, *}$, Pia H. Moisander ${ }^{2}$, Joachim W. Dippner ${ }^{1}$, Rachel A. Foster ${ }^{2,5}$, \\ Maren Voss ${ }^{1}$, Birte Karfeld ${ }^{3}$, Jonathan P. Zehr ${ }^{2}$ \\ ${ }^{1}$ Leibniz Institute for Baltic Sea Research, Department of Biological Oceanography, 18119 Warnemuende, Germany \\ ${ }^{2}$ Ocean Sciences Department, University of California Santa Cruz, California 95064, USA \\ ${ }^{3}$ Institute of Oceanography, University of Hamburg, 20146 Hamburg, Germany \\ ${ }^{4}$ Present address: Ocean Sciences Department, University of California Santa Cruz, California 95064, USA \\ ${ }^{5}$ Present address: Max Planck Institute for Marine Microbiology, Celsiusstr. 1, 28359 Bremen, Germany
}

\begin{abstract}
N}_{2}$ fixation by marine pelagic prokaryotes plays a critical role in supplying new $\mathrm{N}$ to the ocean, and there is growing evidence that oceanic $\mathrm{N}_{2}$ fixation is generally enhanced in tropical river plumes, where $\mathrm{N}_{2}$ fixers (diazotrophs) benefit from riverine phosphorus and/or iron. Here we used nifH gene quantitative polymerase chain reaction (QPCR) and reverse transcription (RT) QPCR to investigate the horizontal distribution and activity of 9 diazotroph phylotypes in the Mekong River plume, South China Sea (SCS), in April 2007 (intermonsoon, lowest annual discharge). The nifH gene diversity was investigated by cloning and sequencing. Hydrodynamic modeling of the surface water advection revealed that the same water masses were sampled during the entire study, and helped to elucidate the physical forcing on diazotroph abundances and distributions. According to our estimates of nifH abundances and expression, the high $\mathrm{N}_{2}$ fixation rates detected in the Mekong plume can primarily be attributed to Trichodesmium spp. and the symbiotic diatom-diazotroph associations (DDAs) Rhizosolenia-Richelia and Hemiaulus-Richelia. NifH phylotypes from unicellular cyanobacterial groups B and C and a gammaproteobacterial group (24774A11) were exclusively detected and expressed at oceanic stations. Clone libraries of nifH were dominated by Trichodesmium spp. but also included proteobacterial- and cluster III-like nifH sequences, including new lineages, possibly representing other active diazotrophs in the Mekong plume and SCS offshore waters. This study extends the known distribution of quantitatively important oceanic diazotrophs, and shows that the Mekong River plume hosts a diverse diazotroph community, of which particularly Trichodesmium spp. and DDAs fix $\mathrm{N}_{2}$ at high rates.
\end{abstract}

KEY WORDS: Nitrogen fixation · Phytoplankton ecology $\cdot$ Trichodesmium $\cdot$ Diatoms $\cdot$ Symbiosis South China Sea $\cdot$ River discharge

Resale or republication not permitted without written consent of the publisher

\section{INTRODUCTION}

Dinitrogen $\left(\mathrm{N}_{2}\right)$ fixation by pelagic prokaryotes in tropical and subtropical seas represents the largest external source of biologically available nitrogen to the ocean (Karl et al. 2002, Gruber \& Galloway 2008). The filamentous, bloom-forming cyanobacterium Trichodesmium spp. alone account for a large proportion of oceanic $\mathrm{N}_{2}$ fixation (Capone et al. 1997, 2005, LaRoche \& Breitbarth 2005). Other quantitatively important $\mathrm{N}_{2}$ fixers (diazotrophs) are the symbiotic diatomdiazotroph associations (DDAs) between the heterocystous cyanobacterium Richelia intracellularis and Rhizosolenia spp. and Hemiaulus spp., or alternatively between the symbiont Calothrix rhizosoleniae and the diatoms Chaetoceros spp. (Villareal 1992, Janson et al. 
1999, Foster \& Zehr 2006). Further, by analyzing the diversity and distribution of the nifH gene (encoding the iron-containing subunit of nitrogenase enzyme), previously unrecognized unicellular microbes were discovered in the marine environment (Zehr \& McReynolds 1989, Zehr et al. 1998). Many subsequent studies have focused on unicellular cyanobacterial diazotrophs, and results suggest that they as well contribute substantially to oceanic $\mathrm{N}_{2}$ fixation (Zehr et al. 2001, Montoya et al. 2004, Church et al. 2005a).

Although $\mathrm{N}_{2}$ fixation is recognized as a key component of the oceanic nitrogen cycle, it remains challenging to reliably integrate diazotroph inputs over large spatial scales. In order to improve these estimates, it is necessary to better understand how environmental factors control the distributions of various diazotroph species. Diazotroph communities appear to differ between surface waters of the open ocean, deeper waters, and the coastal ocean, reflecting different selective pressures acting on diazotrophs in these environments (Zehr et al. 2003). Trichodesmium spp. and different unicellular diazotrophic cyanobacteria are frequently found in warm surface waters of the oligotrophic open ocean, where their growth can be limited by phosphorus and iron availability (Sañudo-Wilhelmy et al. 2001, Kustka et al. 2002, Mills et al. 2004). However, later studies showed that these major groups have more distinct spatial distributions, with group A unicellular cyanobacteria (UCYN-A) generally occurring deeper in the water column and at lower temperatures compared to group B unicellular cyanobacteria (UCYN-B, Crocosphaera watsonii) and Trichodesmium spp. (Langlois et al. 2008, Moisander et al. 2010). Further, in contradiction to traditional beliefs that river-influenced sites are unfavorable for diazotrophs, coastal areas and tropical river plumes farther offshore can be characterized by high rates of $\mathrm{N}_{2}$ fixation (Moisander et al. 2002, Chan et al. 2006, Bonnet et al. 2009). A prominent example comes from the western tropical north Atlantic (WTNA), where rates of $\mathrm{N}_{2}$ fixation in the Amazon River plume exceeded vertical nitrate fluxes (Carpenter et al. 1999). The diazotroph community in this river plume mainly consisted of the DDAs Hemiaulus-Richelia, which presumably benefit from the combined riverine inputs of phosphorus, silicate, and iron (Carpenter et al. 1999, Foster et al. 2007). Unlike Trichodesmium spp. and other diazotrophs, the fast-sinking DDAs efficiently contribute to the sequestration of atmospheric carbon in the deep sea (Scharek et al. 1999a,b, Mulholland 2006, Subramaniam et al. 2008). It was assumed that high $\mathrm{N}_{2}$ fixation, in particular carried out by DDAs, could be a general phenomenon in tropical river plumes (Subramaniam et al. 2008), but few other studies in such systems have been conducted. In the framework of a Vietnamese-German research project, we had an opportunity to investigate diazotroph distributions and activities in surface waters of the South China Sea (SCS) which are affected by the Mekong River, the 10th largest river of the world by discharge (Perry et al. 1996).

To date, the impact of Mekong runoff on the biogeochemistry and phytoplankton species distribution in the SCS has rarely been described in the literature. There are pronounced differences in discharge of water and nutrients between different monsoon seasons, with $85 \%$ of the total annual outflow (about $500 \mathrm{~km}^{3}$ ) occurring during the southwest (SW) monsoon when the river plume flows northeast-ward towards the open SCS (Le et al. 2007). In contrast, the plume flows near shore in a southwesterly direction during the northeast (NE) monsoon (November to March) and during intermonsoon (April) when the discharge reaches its annual minimum (Le et al. 2007). We investigated pelagic $\mathrm{N}_{2}$ fixation and phytoplankton species distributions in the area in April 2007 and September 2008. During both cruises, very high rates of $\mathrm{N}_{2}$ fixation were measured in surface waters affected by the Mekong plume, with up to $22.77 \mathrm{nmol} \mathrm{N}^{-1} \mathrm{~h}^{-1}$ in April 2007, covering up to $47 \%$ of the $\mathrm{N}$ demand of primary productivity (Grosse et al. 2010). However, by light microscopy it was impossible to unambiguously identify the responsible diazotrophs. Therefore, in the present study, surface samples taken in April 2007 were used to investigate the horizontal distribution and activity of 9 diazotroph phylotypes, using nifH gene quantitative polymerase chain reaction (QPCR) and reverse transcription (RT)-QPCR assays, respectively. Additionally, the nifH gene diversity along the salinity gradient was assessed by cloning and sequencing. In order to better understand and interpret our measures of $\mathrm{N}_{2}$ fixation and diazotroph community distributions, we simulated the surface flow of the river plume along the coast using a hydrodynamic model.

\section{MATERIALS AND METHODS}

Sampling. Samples were collected along 3 transects (Fig. 1a) between 15 and 20 April 2007, aboard the Vietnamese monitoring vessel 'BTh-0666 KN.' Total distances between coastal stations and stations farthest offshore were $29 \mathrm{~km}$ and $41 \mathrm{~km}$ on transects 1 and 3, respectively, and $135 \mathrm{~km}$ on transect 2 . Stn 19 , a $25 \mathrm{~h}$ mooring station, was sampled in order to describe the hydrography of the Mekong River plume throughout a complete tidal cycle (B. Karfeld et al. unpubl.; used for model validation). At all stations, we recorded profiles of conductivity, temperature, and depth (CTD) using a Seabird SBE19 plus sensor with measurement error of 0.01 for salinity. Turbidity profiles were recorded with an infrared turbidity meter recording nephelometric 


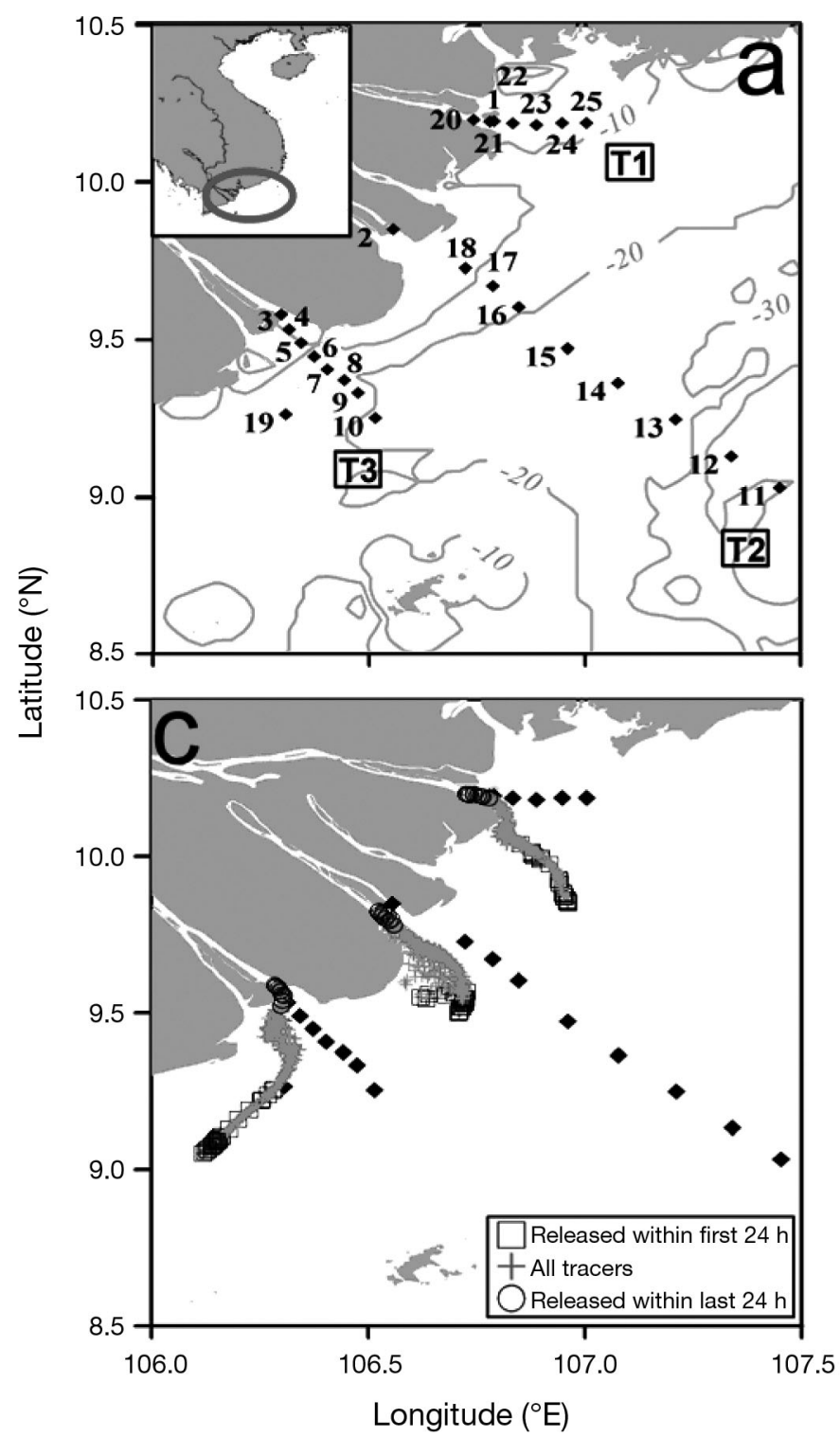

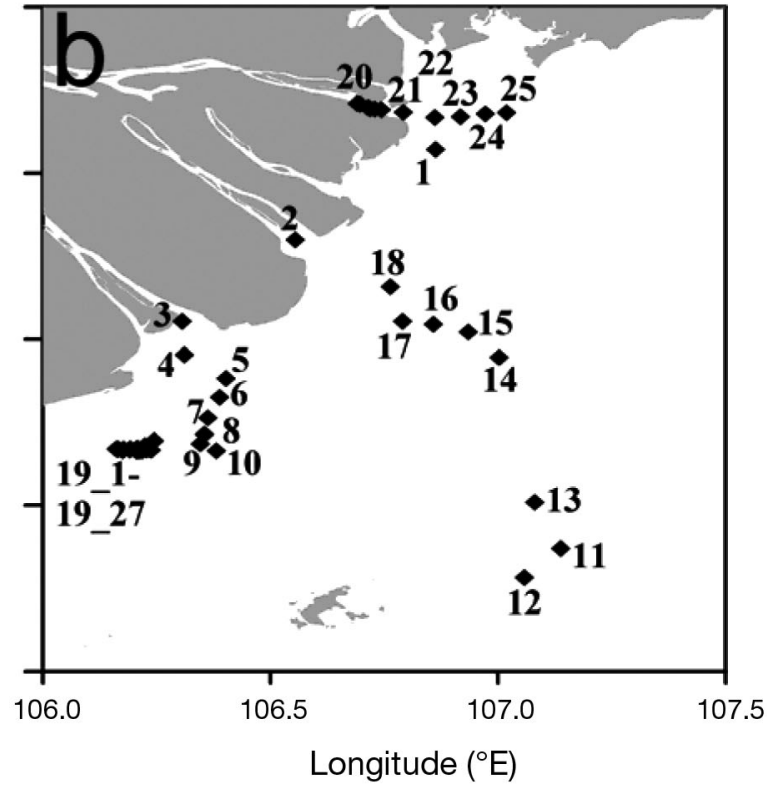

Fig. 1. (a) Mekong River Estuary, showing locations of CTD-stations (Eulerian station coordinates) on transects 1 (T1), 2 (T2), and 3 (T3). (b) Using the modified HAMSOM model, stations were transformed onto Lagrangian coordinates, i.e. coordinates relative to the time when the last station (Stn 25, 4 April 2007, 08:30 h) was sampled. (c) Propagation of the Mekong River plume between 9 April 2007, 00:00 h and 22 April 2007, 00:00 h, as shown by results of a Lagrangian tracer experiment in HAMSOM. From coordinates of Stns 1, 2, and 3, 1 tracer was released every hour for a model run of 335 h. In (c), the Eulerian sampling stations are included to show their posi-tion relative to the modeled plume propagation turbidity units (NTU), with a measurement error of 0.5 NTU (Seapoint). In total, 27 surface water samples were taken with a 101 Niskin bottle. Mooring Stn 19 was sampled hourly by CTD between 06:00 h on 18 April 2007 and 07:00 h on 19 April 2007 (local times), but here we only report data from 7 consecutive time points (19_1 for cast 1 and so on), during which samples were collected for nucleic acids and chemical parameters described below. The vertical distribution of photosynthetically active radiation (PAR) was measured using a LICOR spherical light sensor. PAR measurements were limited to Stns 1, 3, 5, and 12, because the sensor was not deployable at most stations due to strong tidal currents (up to $1.8 \mathrm{~m} \mathrm{~s}^{-1}$ ).

Nutrient analyses. Surface samples were collected at 27 stations to determine concentrations of nitrate
$\left(\mathrm{NO}_{3}{ }^{-}\right)$, nitrite $\left(\mathrm{NO}_{2}{ }^{-}\right)$, phosphate $\left(\mathrm{PO}_{4}{ }^{3-}\right)$, and silicate $\left(\mathrm{Si}(\mathrm{OH})_{4}\right)$. The water samples were immediately frozen after filtration, and nutrients were analyzed at the Institute of Oceanography in Nha Trang, Vietnam, using standard colorimetric methods (Grasshoff et al. 1983). Under the local circumstances, detection limits were $0.05 \mu \mathrm{mol} \mathrm{l} \mathrm{l}^{-1}$ for $\mathrm{NO}_{3}, \mathrm{NO}_{2}$, and $\mathrm{PO}_{4}$, and $0.1 \mu \mathrm{mol}$ $\mathrm{l}^{-1}$ for $\mathrm{Si}(\mathrm{OH})_{4}$. Nutrient ratios $(\mathrm{N}: \mathrm{P}, \mathrm{Si}: \mathrm{N})$ were only calculated for samples above these detection limits. Nutrients are hereafter termed $\mathrm{N}$ for $\mathrm{NO}_{3}{ }^{-}+\mathrm{NO}_{2}{ }^{-}, \mathrm{P}$ for $\mathrm{PO}_{4}{ }^{3-}$, and $\mathrm{Si}$ for $\mathrm{Si}(\mathrm{OH})_{4}$.

$\mathbf{N}_{2}$ fixation. Rates of $\mathrm{N}_{2}$ fixation were measured in triplicate surface water samples at 15 stations, using tracer assays described previously (Montoya et al. 1996). At each station, 3 polycarbonate bottles (2.3 l each) were filled and sealed with Teflon-coated butyl- 
rubber septa, and $2 \mathrm{ml}$ of ${ }^{15} \mathrm{~N}_{2}$ gas (Sercon, 99 atom\%) were added with a syringe. The bottles were shaken by hand for ca. 3 min to facilitate the dissolution of the ${ }^{15} \mathrm{~N}_{2}$ gas, and then incubated on deck under simulated in situ conditions, using neutral density screening $(50 \%)$ and surface sea water for cooling. During the incubations, the bottles were gently agitated by the constant movement of our small vessel, which further facilitated the equilibration of the ${ }^{15} \mathrm{~N}_{2}$ gas bubble with the seawater. Because of the limited cruise time during the investigation, incubations were always initiated immediately after sampling. Most daylight incubations lasted either from around 06:00 to 12:00 h or from 12:00 to $18: 00 \mathrm{~h}$. Incubations during the night covered the entire dark period $(12 \mathrm{~h})$. Incubations were terminated by gentle filtration over precombusted Whatman GF/F filters. The remaining protocols followed Montoya et al. (1996).

Nucleic acid sampling and extraction. DNA and RNA samples were collected from the surface at 18 stations, including samples from 11 transect stations and 7 samples from mooring Stn 19. Seawater from the Niskin bottles was collected into 21 acid-washed polycarbonate bottles. Immediately after sampling, between 150 and $1100 \mathrm{ml}$ (depending on turbidity) were filtered onto $0.2 \mu \mathrm{m}$ pore size Durapore (Millipore) filters, held in $25 \mathrm{~mm}$ diameter Sartorius filter holders, using a peristaltic pump. For DNA samples, seawater was size fractionated by pre-filtering through $10 \mu \mathrm{m}$ pore size Isopore filters (Millipore). The filters were removed, placed into $1.5 \mathrm{ml}$ cryovials, and stored in liquid nitrogen until arrival in the lab, where they were stored at $-80^{\circ} \mathrm{C}$

A FastDNA ${ }^{\circledR}$ Pro Soil kit (MPI Biomed) was used for DNA extraction. We closely followed the manufacturer's extraction protocol, which includes a purification step for humic substances. RNA was extracted using a modified Qiagen RNeasy kit protocol. Sample filters were transferred into sterile bead beater tubes containing $350 \mu$ l of RLT buffer from the kit, $1 \% \beta$-mercaptoethanol, and $30 \mu \mathrm{l}$ of $0.1 \mathrm{~mm}$ glass beads (Biospec Products). The tubes were agitated in a bead beater (Mini-Beadbeater-96; Biospec) for 2 min, filters were removed, and the tubes were centrifuged for $1 \mathrm{~min}$ at $8000 \times g$. The supernatants were transferred to Qiagen shredder columns, centrifuged for $2 \mathrm{~min}$ at the maximum speed, and then transferred to clean $1.5 \mathrm{ml}$ microcentrifuge tubes. The RNA purification was completed using RNeasy spin columns, following the manufacturer's protocol. An on-column DNAse step was included with a $1 \mathrm{~h}$ incubation. The RNA was eluted in $35 \mu \mathrm{l}$ of RNAse-free water and stored at $-80^{\circ} \mathrm{C}$.

nifH PCR, cloning, sequencing, and sequence analyses. Diversity of the diazotroph populations was investigated by amplifying, cloning, and sequencing a
359 base pair (bp) fragment of the nifH gene from surface water samples taken at 8 stations $(2,3,8,10,12$, 15, 18, and 19_1, 05:30 hi Fig. 1). We used a previously described nested PCR approach with degenerate primers (Zehr \& Turner 2001). Amplified products were purified and cloned into pGEM-T vectors (Promega), and sequenced to both directions at the University of California Berkeley sequencing facility, using SP6 or T7 primers. Sequences were trimmed and integrity-checked using phred-phrap (Ewing et al. 1998). For each sample, sequences were considered different if they differed by more than $1 \mathrm{bp}$. Representative sequences $(\mathrm{n}=57)$ were deposited to GenBank under accession numbers GQ475428 to GQ475484. For phylogenetic analyses, the edited sequences were translated and imported into an aligned ARB database (Zehr et al. 2003). Neighbor-joining trees were constructed in ARB (Ludwig et al. 2004) with Kimura correction (Kimura 1983) with translated sequences.

cDNA synthesis. RNA was reverse transcribed using a Super-Script III first strand cDNA synthesis kit (Invitrogen), following the manufacturer's protocol. The $20 \mu \mathrm{l}$ reactions contained $5 \mu \mathrm{l}$ of RNA template, $0.5 \mu \mathrm{mol} \mathrm{l}^{-1}$ reverse primer nifH 2 (Zehr \& Turner 2001), $0.5 \mathrm{mmol} \mathrm{l}^{-1} \mathrm{dNTP}$ mixture, $2 \mu \mathrm{l}$ of $10 \times$ RT-buffer, $5 \mathrm{mmol} \mathrm{l}^{-1} \mathrm{MgCl}_{2}, 10 \mathrm{mmol} \mathrm{l}^{-1}$ dithiothreitol, $2 \mathrm{U} \mathrm{\mu l}^{-1}$ RnaseOUT (Invitrogen), and $10 \mathrm{U} \mathrm{\mu l}^{-1}$ reverse transcriptase (RT). Negative control reactions included a reaction with no RT and sample RNA (controls for DNA contamination), and a reaction with RT but template replaced with water. Reaction conditions were as follows: $50^{\circ} \mathrm{C}$ for $50 \mathrm{~min}, 85^{\circ} \mathrm{C}$ for $5 \mathrm{~min}$, then tubes were placed on ice. Subsequently, $1 \mu \mathrm{l}$ of RNase H was added to each reaction mixture, and tubes were incubated at $37^{\circ} \mathrm{C}$ for 20 min to eliminate residual RNA. The cDNA was stored at $-20^{\circ} \mathrm{C}$.

Quantitative PCR and RT-QPCR. Taq-Man ${ }^{\circledR}$ primerprobe sets that were previously designed for 9 oceanic diazotroph phylotypes were used to quantify nifH abundance and expression in QPCR assays (Table S1 in the Supplement at www.int-res.com/articles/suppl/ m424p039_supp.pdf). QPCR reactions were conducted in a 7500 Real-Time PCR system (Applied Biosystems). QPCR reactions for samples were run in triplicate. Standard curves and PCR efficiency tests were carried out as described previously (Short et al. 2004, Short \& Zehr 2005). Primer and probe sets specific for DDA symbionts and Trichodesmium spp. were used to detect targets in DNA extracts from both the $10 \mu \mathrm{m}$ and $0.2 \mu \mathrm{m}$ pore size filters, and gene copy abundances in the 2 size fractions were pooled. Standard curve linear regression $r^{2}$ values were $>0.98$ for all reactions. Amplification efficiencies were $\geq 98.1 \%$ in all samples, except for 1 lower value in the sample from Stn $12(95.7 \%$ in a reaction targeting Tricho- 
desmium spp. DNA). Thus, all QPCR reactions were considered uninhibited. If only 2 of the 3 replicates produced an amplification signal, the target was noted as detected, but not quantifiable.

In this study, data from QPCR/RT-QPCR assays were used to identify the presence of different diazotrophs and to indicate their active participation in $\mathrm{N}_{2}$ fixation at the different sampling stations. When comparing abundances of nifH gene copies between different stations, it must be kept in mind that absolute target abundances may be slightly variable, since multiple nifH gene copies per genome (so far only precluded for Trichodesmium spp., UCYN-A, and UCYN-B cyanobacteria), or multiple genomes per cell could exist. In the following, we refer to the quantified nifH genes and transcripts of the cyanobacterial symbionts with the abbreviations $R-R$ for Rhizosolenia-Richelia (het-1), $H$ - $R$ for Hemiaulus-Richelia (het-2), and $C-C$ for Chaetoceros-Calothrix (het-3), assuming that the symbionts were not free-living, but associated with their respective diatom hosts.

Transformation onto Lagrangian coordinates and a Lagrangian tracer experiment. We used a circulation model to characterize spatial and temporal patterns of the river plume propagation along the coast during intermonsoon flow conditions. B. Karfeld et al. (unpubl. data) simulated the circulation in the Mekong estuary, using an updated version of the numerical Hamburg Shelf Ocean Model (HAMSOM; Backhaus 1985, Pohlmann 2006). HAMSOM is a 3-dimensional, baroclinic, primitive equation model with a free surface (Backhaus 1985). We used a temporal resolution of $2.5 \mathrm{~min}$, and a horizontal grid resolution of $1 / 60^{\circ}$. Hydrographic measurements from our study were used to validate the model results (Hein et al. 2007).

Two Lagrangian tracer experiments were carried out in surface currents calculated by HAMSOM. In the first experiment, we transformed our sampling stations onto Lagrangian coordinates (fixed in time), using the reference time of Stn 25, the last station sampled (4 April 2007, 08:30 h). This technique eliminates the effects of 'tidal aliasing,' i.e. the biased picture of the distribution of hydrographic parameters on fixed oceanographic stations which can result from the intermittent sampling of station transects across tideadvected water masses over time periods of several days (Brockmann \& Dippner 1987). By the assumption of no vertical mixing, this technique allows the reconstruction of quasi-synoptic observations of the hydrography. In the second experiment, 1 tracer was released every hour for a model run of $335 \mathrm{~h}$ from Stns 1, 2, and 3 (9 April 2007, 00:00 h until 22 April 2007, 00:00 h). This experiment aimed at resolving the temporal scales at which the river plume flows along the coast, and at visualizing the frontal dynamics in this tidally- driven estuary. In both experiments, surface advection incorporated the effects of tides, river runoff, wind stress, and remote forcing due to boundary currents.

Statistical analyses. Correlations, linear regressions, and curve fittings were performed in SPSS 15.0 for Windows and Grapher 6.0 (Golden Software).

\section{RESULTS}

\section{Lagrangian tracer experiments}

There was only limited spatial displacement of the geographically fixed sampling stations by the transformation onto Lagrangian coordinates (Fig. 1a,b). The results of the tracer release experiment show the extension of the river plume front and the alongshore propagation of the plume in a south-westerly direction (Fig. 1c). The 'oldest' tracers are found farthest offshore, and tracers originating from Stn 3 spread in a southwesterly direction along a straight line. Within $335 \mathrm{~h}$, the tracers covered a net distance of approximately $46 \mathrm{~km}$ across the shelf, and a maximum alongshore distance of $63 \mathrm{~km}$.

\section{Environmental conditions}

We distinguish 3 station categories based on surface salinity, turbidity, and nutrient concentrations, and these categories will be referred to throughout this paper: (1) plume stations (salinity 14.3 to 29), (2) transitional stations (salinity 32 to 33.5), and (3) oceanic stations (salinity $>33.5$ ). The isolines of salinity defining the transitional zone are highlighted in figures showing surface distributions. The lowest salinity of 14.3 was observed at the plume Stn 3, from which salinities gradually increased towards oceanic stations (maximum of 34, Stn 13; Fig. 2a). All 7 samples taken at mooring Stn 19 fell into the salinity category 'transitional.'

Sea surface temperatures varied little between 28.5 and $31.5^{\circ} \mathrm{C}$ in the entire area, with the lowest temperatures at oceanic Stns 11 and 12, and the highest temperature at plume Stn 3 (data not shown).

Highly turbid surface waters (NTU $\geq 27$ ) were largely confined to the area where depths were shallower than $20 \mathrm{~m}$, i.e. to plume stations (Figs. 1a \& 2b). Turbidity was clearly higher at transitional stations ( 2 to 9 NTU) than at oceanic stations ( $\leq 1$ NTU). At plume Stns 1, 3, and 5, where turbidity was between 42 and 79 NTU, PAR decreased to less than $50 \%$ of the surface value within the first meter of the water column, and to less than $1 \%$ at 2 m depth (data not shown). In contrast, at Stn 12, surface turbidity was below detection $(<0.5 \mathrm{NTU})$, and PAR was still $40 \%$ of the surface value at $5 \mathrm{~m}$ depth. 

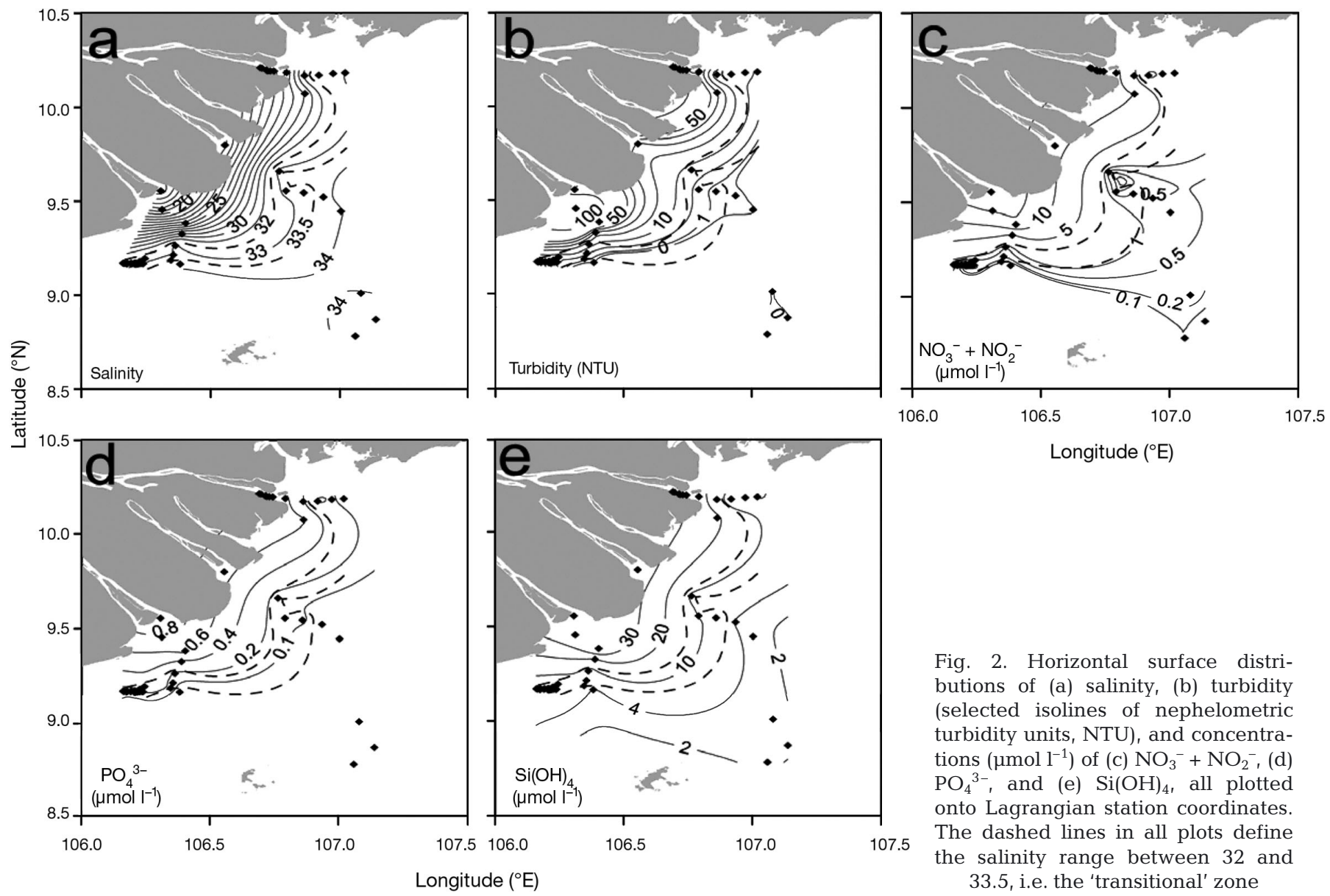

Fig. 2. Horizontal surface distributions of (a) salinity, (b) turbidity (selected isolines of nephelometric turbidity units, NTU), and concentrations $\left(\mu \mathrm{mol} \mathrm{l} l^{-1}\right.$ ) of (c) $\mathrm{NO}_{3}{ }^{-}+\mathrm{NO}_{2}{ }^{-}$, (d) $\mathrm{PO}_{4}{ }^{3-}$, and (e) $\mathrm{Si}(\mathrm{OH})_{4}$, all plotted onto Lagrangian station coordinates. The dashed lines in all plots define the salinity range between 32 and 33.5 , i.e. the 'transitional' zone

Concentrations of all nutrients also showed strong offshore gradients (Fig. 2c-e), with highest concentrations detected at plume stations $(\mathrm{N} \geq 9.9 \mu \mathrm{M}, \mathrm{P} \geq$ $0.6 \mu \mathrm{M}, \mathrm{Si} \geq 22.0 \mu \mathrm{M})$. Transitional stations had intermediate nutrient concentrations $(\mathrm{N} \leq 0.9 \mu \mathrm{M}, \mathrm{P} \leq$ $0.3 \mu \mathrm{M}, \mathrm{Si} \leq 10.1 \mu \mathrm{M})$, and at oceanic stations, nutrient concentrations were undetectable or low $(\mathrm{N} \leq 0.3 \mu \mathrm{M}$, P below detection, $\mathrm{Si} \leq 3.6 \mu \mathrm{M})$. Overall, nutrient concentrations as well as turbidity were negatively correlated with salinity (Table 1). There was a significant $(p<0.001)$ negative relationship between surface salinity and the ratio of $\mathrm{N}$ to $\mathrm{P}(\mathrm{N}: \mathrm{P} ;$ Fig. $3 \mathrm{a})$. N:P ratios lower than the Redfield ratio (16:1) were largely confined to transitional waters. Si:N ratios remained $<5$ at plume stations, varied widely between 4 and 49.3 at transitional stations, and between 2.8 and 22 at oceanic stations (Fig. 3b).

\section{$\mathbf{N}_{2}$ fixation}

Rates of $\mathrm{N}_{2}$ fixation were measured at several stations within the plume (Stns 1 to 3, and 20_1), transi- tional waters $(8,18,19)$ and within oceanic waters $(10$, 11,15 ; Table 2; discussed in detail by Grosse et al. 2010). $\mathrm{N}_{2}$ fixation was detectable at all of these stations. Daytime $\mathrm{N}_{2}$ fixation ranged from $0.59 \mathrm{nmol} \mathrm{N}^{-1}$ $\mathrm{h}^{-1}$ (plume Stn 20_1) to $22.77 \mathrm{nmol} \mathrm{N} \mathrm{l^{-1 }} \mathrm{h}^{-1}$ (transitional Stn 19_9). The highest rates of $\mathrm{N}_{2}$ fixation were detected at transitional and oceanic stations having surface salinities $\geq 32.6$ and relatively low nutrient concentrations (Table 2).

Table 1. Pearson correlation matrix comparing changes in salinity, turbidity, and nutrient concentrations in surface waters. $p \leq 0.01$ is considered significant

\begin{tabular}{|lccc|}
\hline & Salinity & $\mathrm{p}$ & $\mathrm{n}$ \\
\hline Salinity & 1.000 & & 32 \\
Turbidity & -0.778 & $\leq 0.001$ & 32 \\
Nitrate & -0.822 & $\leq 0.001$ & 27 \\
Nitrite & -0.603 & $\leq 0.001$ & 27 \\
Phosphate & -0.919 & $\leq 0.001$ & 27 \\
Silicate & -0.931 & $\leq 0.001$ & 27 \\
\hline
\end{tabular}




\section{Abundances of diazotrophs and nifH gene expression}

Gene copy abundances and expression of nifH in different phylotypes was quantified at all stations where $\mathrm{N}_{2}$ fixation was measured, and additionally at Stns 5, 12, and 18 (Table 2).

$N i f H$ gene copies and transcripts of the 'larger' diazotrophs (Trichodesmium spp., $R-R$, and $H-R$ ) were mainly found at transitional and oceanic stations (Fig. 4, Table 2), which were characterized by low N:P ratios $(\leq 5.1)$, low $\mathrm{N}$ concentrations $(\leq 0.9 \mu \mathrm{mol} N)$, and highest $\mathrm{N}_{2}$ fixation rates. $H-R\left(4.5 \times 10^{3}\right.$ nifH gene copies $\left.\mathrm{l}^{-1}\right)$ and Trichodesmium spp. $\left(5.7 \times 10^{3}\right.$ nifH gene copies $\mathrm{l}^{-1}$ ) were also found at plume Stn 2 , where N concentrations and the N:P ratio were high $(11.6 \mu \mathrm{mol}$ $\mathrm{l}^{-1}$; 17.6). However, nifH expression was not detected, and $\mathrm{N}_{2}$ fixation rates were comparatively reduced $\left(1.01 \pm 0.31 \mathrm{nmol} \mathrm{N} \mathrm{l}^{-1} \mathrm{~h}^{-1}\right)$. Similarly, Trichodesmium spp. was present with no detectable nifH gene expression at plume Stn 20_1 $\left(2.1 \times 10^{3}\right.$ nifH gene copies $\left.\mathrm{l}^{-1}\right)$ and Stn $3\left(3.0 \times 10^{4}\right.$ nifH gene copies $\left.\mathrm{l}^{-1}\right)$, which had high $\mathrm{N}$ concentrations, high $\mathrm{N}: \mathrm{P}$, and low $\mathrm{N}_{2}$ fixation (Table 2). Unicellular diazotrophs (UCYN-B, UCYN-C, and Gammaproteobacteria) were exclusively quantifiable and expressing nifH in samples from the largely oligotrophic oceanic stations (Fig. 4, Table 2). In some samples from transitional Stn 19, nifH expression was undetected for all 3 of the large diazotroph groups, although rates of $\mathrm{N}_{2}$ fixation were high (19_1, 19_9, and 19_21; Table 2). Gene copies or transcripts of the $C-C$ symbiosis, the Alphaproteobacteria, and UCYN-A cyanobacteria were not quantifiable in any of the samples.

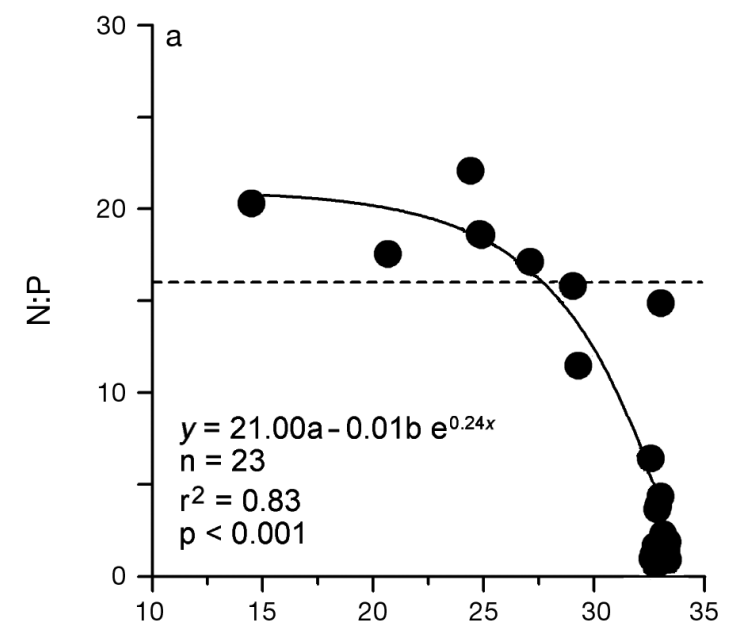

\section{nifH diversity and phylotype distributions}

In total, 82 nifH sequences were recovered from the 8 clone libraries amplified from surface samples, of which 52 sequences were considered unique. These sequences fell into clusters I and III according to the lineages defined by Zehr et al. (2003). Of the 82 total sequences, 24 were within the cyanobacterial lineage and had $>95 \%$ amino acid sequence identity to Trichodesmium erythraeum. These sequences were recovered from oceanic and transitional Stns 10, 15, 18, and 19_1 (05:30 h), where high abundances of nifH gene copies of Trichodesmium spp. were detected by QPCR. Sequences belonging to unicellular cyanobacterial groups (UCYN-B and UCYN-C) as well as heterocystous symbionts did not appear in the clone libraries.

The 45 remaining cluster I sequences, which were recovered from all stations except Stn 15, had a high identity with diverse proteobacterial sequences found in different ocean basins (Fig. S1 in the Supplement at www.int-res.com/articles/suppl/m424p039_supp. pdf), including gammaproteobacterial sequences recovered from the SCS in April 2006 (e.g. EU052324, EU052591; Moisander et al. 2008). Only 1 sequence (GQ475478, Stn 12) had 99\% amino acid sequence identity with the gammaproteobacterial sequence which was targeted with the QPCR primer-probe set in this study and previously (clone 24774A11, EU052413; Moisander et al. 2008). All other proteobacterial nifH sequences would not have been amplified by the applied gamma- and alphaproteobacterial primer-probe sets. The clone libraries also contained sequences from Stns 2, 3, 10, 12, 18, and 19_1 that had between 90 and $98 \%$ protein identity with sequences

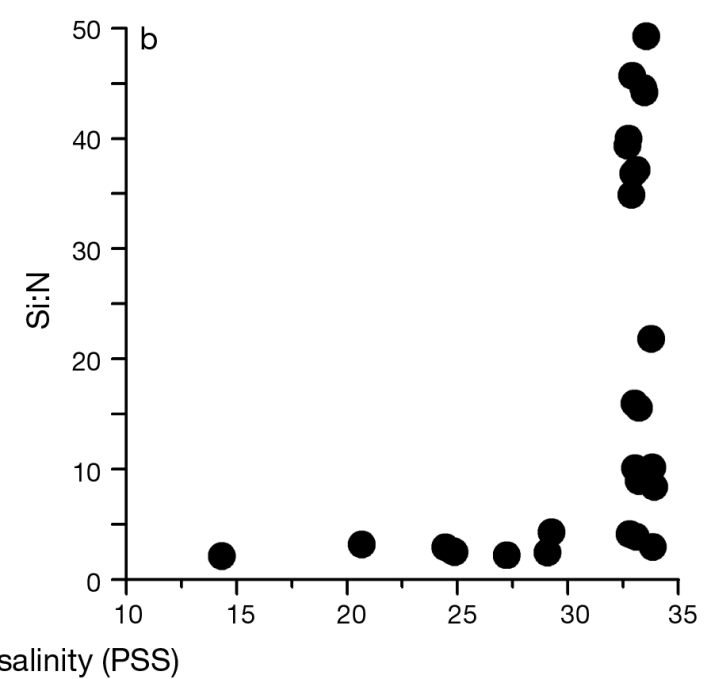

Fig. 3. Relationship between surface salinity and (a) N:P ratios, and (b) Si:N ratios. Horizontal dashed line in (a) represents the Redfield ratio of $16: 1$ 


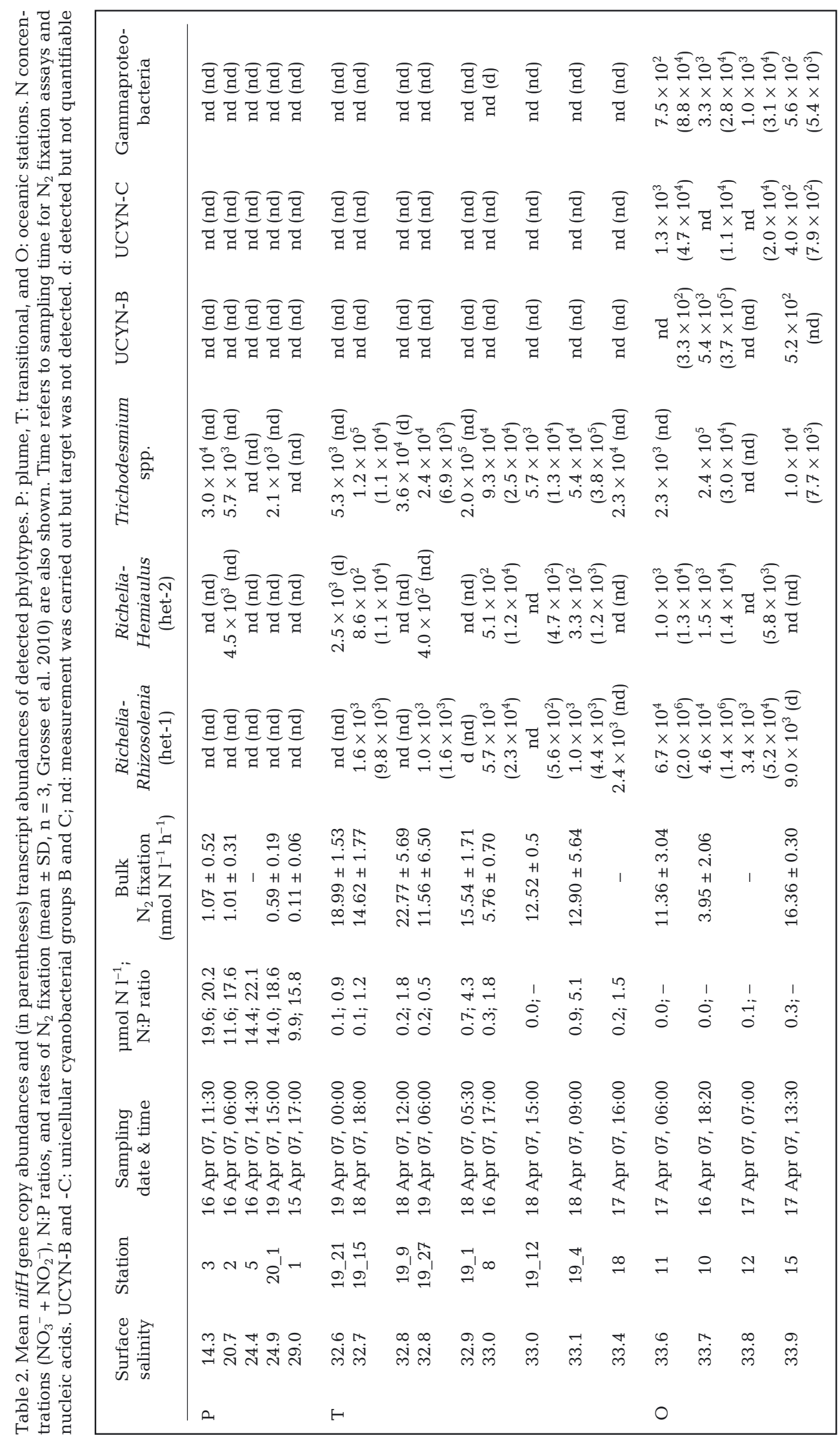




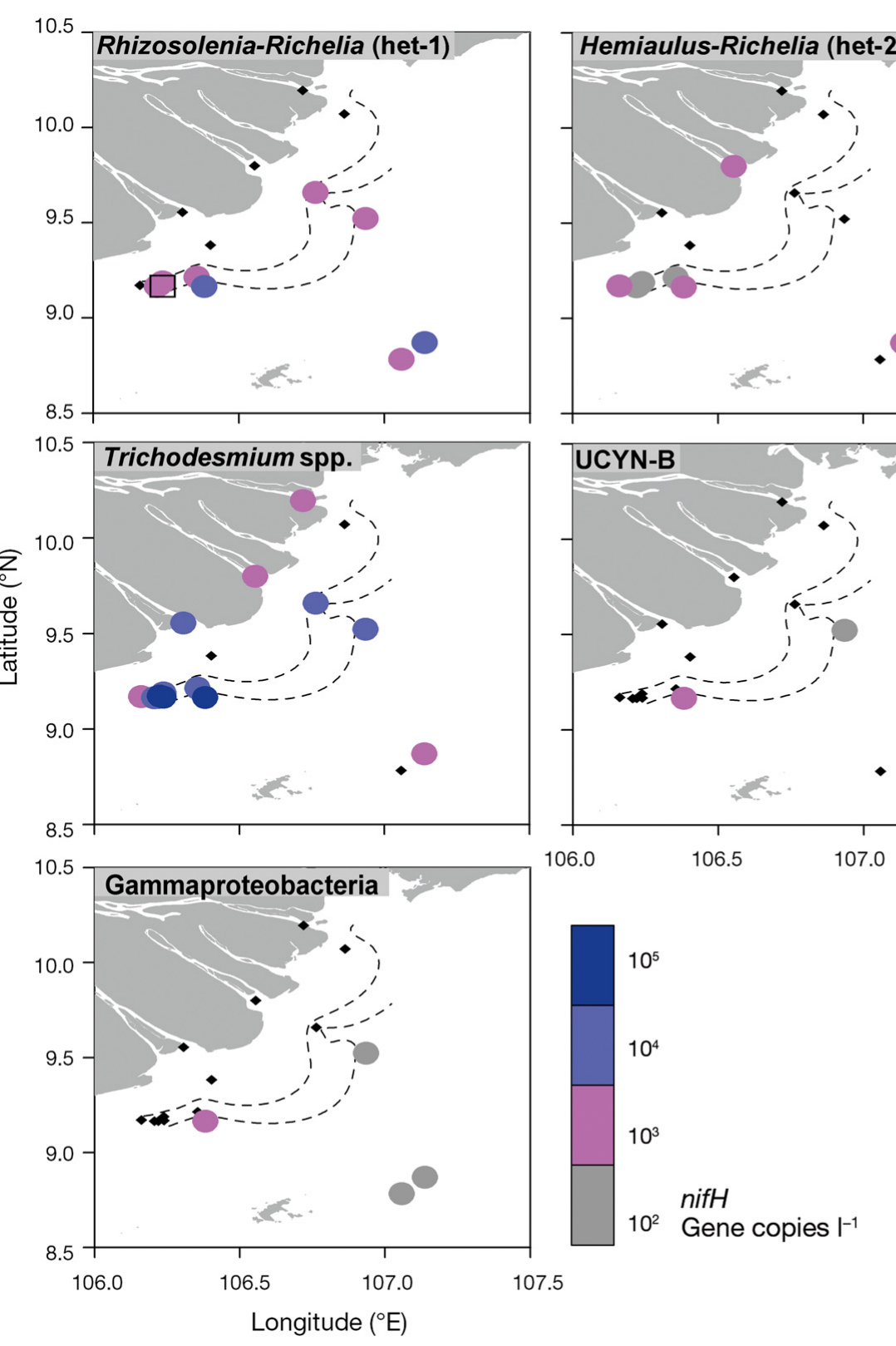

Fig. 4. Horizontal surface distribution of nifH gene copies $1^{-1}$ of the 3 different diatom-diazotroph associations (DDAs), Trichodesmium spp., unicellular cyanobacteria (UCYN-B and UCYN-C), and Gammaproteobacteria. Black squares indicate samples in which nifH gene copies were detected but not quantifiable. Diamonds indicate sampled stations where nifH gene copies of the different phylotypes were not detected. The dashed lines define the salinity range between 32 and 33.5, i.e. the 'transitional' zone

retrieved from the rhizosphere of the salt marsh cordgrass Spartina alterniflora (AF389820, Lovell et al. 2000), or with sequences isolated from rice field soil (EF583567).

Thirteen sequences recovered from Stns 2, 8, and 18 were more similar to cluster III-like sequences (Fig. S2 in the Supplement), with 9 sequences from Stn 8 being most similar (91 to $97 \%$ amino acid sequence identity) to sequences recovered from surface waters of the Gulf of Aqaba (Red Sea; EU151779, Foster et al. 2009). Also in this cluster III group, there were 3 sequences from Stns 2 and 18 that were similar (99\% protein identity) to sequences retrieved from the rhizosphere of the salt marsh cordgrass (AY091859, Lovell et al. 2000). One sequence (GQ475474, Stn 18) had $98 \%$ identity at the protein level to a sequence recovered from sediments in Jiaozhou Bay, China (FJ686498). The closest cultivated relatives with sequences in cluster III were anaerobic sulfate reducers (genus Desulfovibrio, 86 to $90 \%$ protein identity).

\section{DISCUSSION}

\section{Succession of biogeochemical conditions and $\mathbf{N}_{2}$ fixation along the estuarine mixing gradient}

$\mathrm{N}_{2}$ fixation is commonly detected in surface waters of the oligotrophic tropical and subtropical oceans. In contrast, river-influenced waters have traditionally 
been viewed as unfavorable sites for $\mathrm{N}_{2}$ fixation, since rivers were thought to only support new production by introducing dissolved nitrogen species to the ocean, including ammonium $\left(\mathrm{NH}_{4}\right)$, which is a known suppressor of nitrogenase activity (Postgate 1982, Mulholland et al. 2001). Further, it was suggested that in estuaries, the short residence times of water masses (Smith 1984, Howarth 1988), elevated turbulence (Moisander et al. 2002), as well as grazing (Chan et al. 2006) and chemical controls (Marino et al. 2002) could reduce the formation of diazotrophic cyanobacterial blooms. Therefore, the observation that $\mathrm{N}_{2}$ fixation by marine diazotrophs can be greatly enhanced by Amazon River discharge was unexpected (Carpenter et al. 1999). Later it was also shown that in the $\mathrm{SCS}, \mathrm{N}_{2}$ fixation occurs at very high and ecologically significant rates in surface waters affected by Mekong River outflow (Voss et al. 2006) (Table 2).

By combining approaches to study hydrography and nutrient setting in the Mekong River plume, we can now provide a clearer picture of how environmental factors determine phytoplankton species selection and lead to enhanced $\mathrm{N}_{2}$ fixation. Modeling of the surface water advection shows that we did not sample different water masses which successively flowed through the study area, but that water masses rather had a residence time in the area that was certainly long enough for a marine phytoplankton community to respond to riverine influence (Fig. 1). Due to differential changes of the availability of N, P, and Si along the mixing gradient between river and oceanic water, conditions for diazotrophs clearly improved towards higher salinities. At plume stations, the high $\mathrm{N}$ availability ( $\mathrm{N}$ concentrations of $\geq 9.9 \mathrm{\mu mol} \mathrm{l}^{-1}$, and possibly also high concentrations of $\mathrm{NH}_{4}{ }^{+}$) likely suppressed $\mathrm{N}_{2}$ fixation by marine diazotrophs (Mulholland et al. 2001), and high N:P ratios indicate P limitation of phytoplankton. Besides this, the decrease of PAR to less than $1 \%$ of the surface value within $2 \mathrm{~m}$ depth indicates that the plume waters nearest to the river mouth were possibly too turbid for the growth of phytoplankton, including photoautotroph diazotrophs. In contrast, at transitional stations, N:P ratios were clearly lower than the Redfield ratio of $16: 1$, and absolute $\mathrm{N}$ concentrations were $\leq 0.9 \mu \mathrm{mol} \mathrm{l}^{-1}$. These conditions represent $\mathrm{N}$ limitation for phytoplankton growth (Goldman \& Glibert 1983), and thus a growth advantage for diazotrophs, which can take up the 'excess' $\mathrm{P}$ while covering their $\mathrm{N}$ demands by fixing $\mathrm{N}_{2}$. Accordingly, the lowest rates of $\mathrm{N}_{2}$ fixation were measured at plume stations, while rates measured at transitional stations exceeded rates at plume and even oceanic stations (Table 2). We are aware that due to the different diurnal periodicity of $\mathrm{N}_{2}$ fixation in different diazotroph species (Church et al. 2005a), rates of $\mathrm{N}_{2}$ fixation cannot be compared between all stations in our study, since measurements were carried out during different times of the day at the different stations. However, each group of stations included morning, midday, and evening stations, and among these, the highest rates were found at transitional stations, while rates were always low at plume stations irrespective of when incubations were initiated.

\section{Influence of the river discharge on the distribution and activity of different diazotrophs}

Studies that analyzed the diversity of the nifH gene in marine environments have identified previously unknown and quantitatively important pelagic diazotroph microorganisms (Zehr \& McReynolds 1989, Zehr et al. 2001), and subsequently, QPCR/RT-QPCR approaches targeting nifH have greatly helped in assessing their distribution and in understanding how environmental factors regulate $\mathrm{N}_{2}$ fixation on the gene level. For example, studies in the oligotrophic North Pacific Ocean revealed the differing diurnal periodicity in $\mathrm{N}_{2}$ fixation of cyanobacteria and proteobacteria by analyzing nifH gene expression (Church et al. 2005a).

In the present study, we analyzed the surface distribution of nifH gene copies and transcripts of several diazotrophs on a station grid extending between the Mekong River mouth and offshore waters, and stations were intermittently sampled during various times of the day. Due to the temporal segregation of nifH gene expression in unicellular cyanobacteria, Trichodesmium spp., and DDAs (Church et al. 2005a), transcript detection is dependent on time of sampling, and thus transcript abundances, like rates of $\mathrm{N}_{2}$ fixation, cannot be directly compared between all stations in our study. However, the RT-QPCR data are useful for determining which diazotroph groups may have contributed to $\mathrm{N}_{2}$ fixation at different stations.

At some stations, there was a discrepancy between nifH expression and rates of $\mathrm{N}_{2}$ fixation (19_1, 19_9, 19_21, Table 2). While the activity of diazotrophs appeared undetectable by looking at a snapshot of nifH expression at the time points of sampling (when $\mathrm{N}_{2}$ fixation incubations were initiated), the overall potential for $\mathrm{N}_{2}$ fixation was revealed by the rate measurements which integrate the $\mathrm{N}_{2}$ fixation activity of the whole diazotroph community over several hours. Apart from Stn 1, all samples in which $\mathrm{N}_{2}$ fixation was detected contained nifH gene copies and/or transcripts of one or several diazotroph phylotypes. Based on the molecular data presented here and the results from light microscopy (Grosse et al. 2010), we hypothesize that DDAs and Trichodesmium spp. were main contributors to $\mathrm{N}_{2}$ fixation within the transitional and the 
oceanic zone, while UCYN-B, UCYN-C, and Gammaproteobacteria were only active at oceanic stations.

The concurrence of N-limiting conditions with the availability of $\mathrm{Si}$ and $\mathrm{P}$ at transitional stations should particularly favor the growth of DDAs. Based on microscopy, diatoms that potentially associate with Richelia intracellularis, including the genera Rhizosolenia and Hemiaulus, were indeed present at all stations and reached highest abundances at transitional and oceanic stations (Grosse et al. 2010). Here we confirm that the diazotroph symbionts of such diatoms were present and actively transcribing nifH at these stations. There was no clear relationship between abundances of host diatoms and abundances of nifH genes of the diazotroph symbionts, and at some stations (e.g. 19_9), diatoms of the genera Rhizosolenia and Hemiaulus were abundant but nifH genes of their respective symbiont remained undetectable. However, nifH gene copies and transcripts of DDAs were found much more frequently and at high abundances at transitional stations compared to plume stations (Fig. 4, Table 2). We propose that the formation of diatom blooms was initiated in plume waters where nutrient concentrations were high, and that the greater abundances of DDA nifH genes at transitional stations represent a diatom population in which the proportion of DDAs increased as the river plume mixed with nutrient-poor ocean water and the incipient N-limitation selected for diazotrophy. Similar changes in the phytoplankton community were assumed to take place in the Amazon River plume, but on much larger spatial scales compared to Mekong River outflow (Foster et al. 2007). According to our modeling approach, the mixing between plume water and nutrient-depleted ocean water occurs on timescales of $<14 \mathrm{~d}$ in the Mekong estuary (Fig. 1c). This time scale appears sufficient for the mentioned progressions to take place within a diatom bloom, as indicated by batch culture experiments with Rhizosolenia, in which the percentage diatom cells associated with Richelia increased from 5 to $65 \%$ within $12 \mathrm{~d}$ as a response to $\mathrm{N}$ depletion (Villareal 1990).

Although the biogeochemical setting seemed particularly favorable for DDAs, Trichodesmium spp. were also frequently detected and actively expressing nifH at transitional stations (Table 2). These results differ from the scenario observed in the Amazon River plume, where DDAs and particularly $H-R$ clearly dominated over all other phylotypes in 'mesohaline' waters (salinities between 31.0 and 34.9), while the typical oceanic diazotrophs Trichodesmium spp. were most abundant in oligotrophic regions that were less influenced by the plume (Foster et al. 2007). Interestingly, in the study subsequent to the one described here (September 2008), which took place during peak discharge from the Mekong, we again found high abun- dances of potentially symbiotic diatoms and high $\mathrm{N}_{2}$ fixation at river-influenced stations (salinities $\geq 32$ ), but in contrast to April 2007, abundances of Trichodesmium spp. were too low for reliable trichome counts (Grosse et al. 2010). This possibly indicates that during higher discharge, DDAs were able to outgrow Trichodesmium spp. and other diazotrophs, because a larger transitional zone formed which persisted longer and thus provided the setting for selective processes to occur on longer timescales.

While DDAs as well as Trichodesmium spp. seemed to be important members of the diazotroph community in transitional waters, active unicellular cyanobacteria (UCYN-B and UCYN-C) exclusively occurred at oceanic stations (Table 2, Fig. 4). This implies that in contrast to DDAs and Trichodesmium spp., these unicellular cyanobacteria were less able to grow under riverine influence. Investigations in the WTNA and in other areas found greatest nifH abundances of unicellular cyanobacteria in high-salinity waters having the lowest N concentrations (Church et al. 2005b, 2008, Foster et al. 2007), suggesting that they are adapted best to such oligotrophic conditions. Temperature additionally constrains the distribution of different diazotrophs. While Trichodesmium spp. grow optimally between 24 and $30^{\circ} \mathrm{C}$ (Breitbarth et al. 2007), some unicellular diazotrophic cyanobacteria, especially UCYN-A, appear to favor cooler waters (Langlois et al. 2005, 2008, Needoba et al. 2007, Moisander et al. 2010). Thus, the relatively high surface water temperatures in the Mekong River plume $\left(\geq 28.5^{\circ} \mathrm{C}\right)$ may also partly explain why unicellular cyanobacteria were only sporadically detected or absent during our study.

The current known diversity and distribution of oceanic heterotrophic diazotrophs suggest that they could also be quantitatively important $\mathrm{N}_{2}$ fixers besides the cyanobacterial diazotrophs (Farnelid \& Riemann 2008), but comparatively little is known about their ecology. NifH genes of a gammaproteobacterium were detected in the SCS in April 2006 and exclusively occurred within the upper $50 \mathrm{~m}$ of the water column, suggesting that these diazotrophs might have a lightdependent metabolism (Moisander et al. 2008). In the present study, this gammaproteobacterium was shown to express nifH, and similar to the unicellular cyanobacterial diazotrophs, nifH gene copies and transcripts were only detectable at oceanic stations (Fig. 4, Table 2). This is consistent with data from the Arabian Sea, where a closely related nifH gene sequence of a gammaproteobacterium was most readily detected in highly oligotrophic surface waters (Bird et al. 2005), and this nifH sequence was also found at station ALOHA in the subtropical North Pacific (Church et al. 2005a). Thus, our findings add to the evidence that these specific diazotrophs are a component of the open 
ocean diazotroph community in tropical and subtropical latitudes.

By using cloning and sequencing techniques, proteobacterial nifH sequences were found in samples from almost all stations, and cluster III-like nifH sequences were recovered from samples representing plume and transitional stations. In accordance with the results from QPCR, a sequence which was most similar to the oceanic gammaproteobacterial sequence (EU052413, Moisander et al. 2008) was only found at oceanic Stn 12 (Fig. S1). Some samples appeared to contain cells that were flushed into the estuary attached to suspended particles, since we recovered proteobacterial and cluster III-like nifH sequences that were similar to sequences recovered from rice field soil or from the rhizosphere of cordgrass (Figs. S1 \& S2). However, there were also many sequences presumably of marine origin, which were similar to sequences obtained from offshore waters of the SCS, the North Pacific, and the Red Sea. Whether some of these sequences represent active marine diazotrophs remains unclear. Possibly, the sequences related to strictly anaerobic diazotrophs (i.e. Desulfovibrio spp.) and other representatives of cluster III are derived from cells which reside in $\mathrm{O}_{2}$ reduced microenvironments within large suspended particles in the highly turbid, nutrient-rich waters off the Mekong River mouth. Proteobacterial and cluster III nifH sequences are often abundant in waters where there is no $\mathrm{N}_{2}$ fixation, and can also be present as contaminants in reagents. Thus, the significance of the cluster III and proteobacterial sequences other than those detected by quantitative RT-PCR is unclear.

\section{CONCLUSIONS}

We have presented data on the distribution and activity of diazotroph microorganisms in a coastal area of the SCS which was partly influenced by the Mekong River plume. Compared to the oligotrophic open ocean, biogeochemical conditions in estuaries and river plumes can vary on short time scales and can be spatially heterogeneous, making it difficult to study phytoplankton dynamics. According to the modeled propagation of the Mekong River plume in April 2007, we sampled the same water masses throughout our study, and thus obtained adequate data to describe the response of the diazotroph community to river inflow. Mixing between river and oceanic water resulted in a transitional zone that provided most favorable conditions for oceanic diazotrophs, and in particular for DDAs, with N:P ratios $<16$ and high $\mathrm{Si}$ availability. Within this zone, we found Trichodesmium spp. and Richelia intracellularis associated with Rhizosolenia and Hemiaulus to be highly active diazotrophs. In con- trast, active unicellular cyanobacterial and a gammaproteobacterial phylotype appeared to be excluded from the river plume, possibly due to their preference for lower temperatures and their adaptation to offshore oligotrophy. Our findings shed light on a complex interplay between hydrography and geochemical processes in the Mekong estuary, which appears to result in diazotroph growth enhanced by $\mathrm{P}$ inputs, and in an unequal distribution of different marine diazotrophs. The mechanisms by which the N:P ratios decreased towards higher salinities remain speculative for now, but likely include desorption of $\mathrm{P}$ from suspended particles (Chase \& Sayles 1980, Jordan et al. 2008) or denitrification in estuarine sediments (Seitzinger 1988). Such mechanisms could likely occur comparably in other tropical estuaries.

As the variety of ecological factors that control oceanic $\mathrm{N}_{2}$ fixation is revealed, regional and global ecosystem models can be further improved to allow for more realistic quantifications of diazotroph inputs, and for predictions of how environmental change will affect them. For the SCS, the construction of dams, increased fertilizer use, increased sewage loading, and mangrove destruction in the Mekong basin will affect sediment loads, freshwater discharge, nutrient fluxes, and nutrient ratios, and will therefore alter the structure and function of the pelagic ecosystem in the SCS which we are just beginning to understand. The SCS is the largest marginal sea in the world and is increasingly affected by human activities (Halpern et al. 2008). The ecosystem could therefore act as a model for studying how changes in land and water use affect tropical marine pelagic ecosystems.

Acknowledgements. We thank T. Pohlmann, R. Peinert, and the staff of the Institute of Oceanography in Nha Trang (ION) for their help in cruise organization; M. Ochiai, R. Beinart, M. Hogan, I. Hewson, R. Paerl, and E. Mondragon at UCSC for laboratory assistance and discussions; and S. Bench and M. Labrenz for bioinformatics assistance. Funding was provided by a grant from the German Science Foundation (Bo768/7-3) to M.V., a Gordon and Betty Moore Marine Investigator Award and a grant from the NSF Emerging Frontiers Program (Center for Microbial Oceanography: Research and Education, grant 0424599) to J.P.Z., and a scholarship from the German Academic Exchange Service (DAAD) to D.B.

\section{LITERATURE CITED}

Backhaus J (1985) A three-dimensional model for the simulation of shelf sea dynamics. Ocean Dyn 38:165-187

Bird C, Martinez Martinez J, O'Donnell AG, Wyman M (2005) Spatial distribution and transcriptional activity of an uncultured clade of planktonic diazotrophic $\gamma$-proteobacteria in the Arabian Sea. Appl Environ Microbiol 71:2079-2085

Bonnet S, Biegala IC, Dutrieux P, Slemons LO (2009) Nitrogen fixation in the western equatorial Pacific: rates, diazotrophic cyanobacterial size class distribution, and biogeo- 
chemical significance. Global Biogeochem Cycles 23: GB3012, doi:10.1029/2008GB003439

Breitbarth E, Oschlies A, LaRoche J (2007) Physiological constraints on the global distribution of Trichodesmiumeffect of temperature on diazotrophy. Biogeosci 4:53-61

Brockmann CW, Dippner JW (1987) Tidal correction of hydrographic measurements. Dtsche Hydrogr Z 40:241-260

Capone DG, Zehr JP, Paerl HW, Bergman B, Carpenter EJ (1997) Trichodesmium, a globally significant marine cyanobacterium. Science 276:1221-1229

Capone DG, Burns JA, Montoya JP, Subramaniam A and others (2005) Nitrogen fixation by Trichodesmium spp.: an important source of new nitrogen to the tropical and subtropical North Atlantic Ocean. Global Biogeochem Cycles 19:1-17

> Carpenter EJ, Montoya JP, Burns J, Mulholland MR, Subramaniam A, Capone DG (1999) Extensive bloom of a $\mathrm{N}_{2}$-fixing diatom/cyanobacterial association in the tropical Atlantic Ocean. Mar Ecol Prog Ser 185:273-283

> Chan F, Marino RL, Howarth RW, Pace ML (2006) Ecological constraints on planktonic nitrogen fixation in saline estuaries. II. Grazing controls on cyanobacterial population dynamics. Mar Ecol Prog Ser 309:41-53

Chase EM, Sayles FL (1980) Phosphorus in suspended sediments of the Amazon River. Estuar Coast Mar Sci 11: 383-391

> Church MJ, Short CM, Jenkins BD, Karl DM, Zehr JP (2005a) Temporal patterns of nitrogenase gene (nifH) expression in the oligotrophic North Pacific Ocean. Appl Environ Microbiol 71:5362-5370

> Church MJ, Jenkins BD, Karl DM, Zehr JP (2005b) Vertical distributions of nitrogen-fixing phylotypes at Stn ALOHA in the oligotrophic North Pacific Ocean. Aquat Microb Ecol 38:3-14

Church MJ, Björkman KM, Karl DM, Saito MA, Zehr JP (2008) Regional distributions of nitrogen-fixing bacteria in the Pacific Ocean. Limnol Oceanogr 53:63-77

Ewing B, Hillier L, Wendl MC, Green P (1998) Base-calling of automated sequencer traces using Phred. I. Accuracy assessment. Genome Res 8:175-185

Farnelid H, Riemann L (2008) Heterotrophic $\mathrm{N}_{2}$-fixing bacteria: overlooked in the marine nitrogen cycle? In: Couto GN (ed) Nitrogen fixation research progress. Nova Science Publishers, New York, NY, p 409-423

Foster RA, Zehr JP (2006) Characterization of diatomcyanobacteria symbioses on the basis of nifH, hetR and 16S rRNA sequences. Environ Microbiol 8:1913-1925

> Foster RA, Subramaniam A, Mahaffey C, Carpenter EJ, Capone DG, Zehr JP (2007) Influence of the Amazon River plume on distributions of free-living and symbiotic cyanobacteria in the western tropical North Atlantic Ocean. Limnol Oceanogr 52:517-532

Foster RA, Paytan A, Zehr JP (2009) Seasonality of $\mathrm{N}_{2}$ fixation and nifH gene diversity in the Gulf of Aqaba (Red Sea). Limnol Oceanogr 54:219-233

Goldman JC, Glibert PM (1983) Kinetics of inorganic nitrogen uptake by phytoplankton. In: Carpenter EJ, Capone DG (eds) Nitrogen in the marine environment. Academic Press, New York, NY, p 233-274

Grasshoff K, Ehrhardt M, Kremling K (1983) Methods of seawater analysis. Verlag Chemie, Weinheim

> Grosse J, Bombar D, Hai ND, Lam NN, Voss M (2010) The Mekong River plume fuels nitrogen fixation and determines phytoplankton species distribution in the South China Sea during low- and high-discharge season. Limnol Oceanogr 55:1668-1680

Gruber N, Galloway JN (2008) An Earth-system perspective of the global nitrogen cycle. Nature 451:293-296

> Halpern BS, Walbridge S, Selkoe KA, Kappel CV and others (2008) A global map of human impact on marine ecosystems. Science 319:948-952

Hein H, Karfeld B, Pohlmann T (2007) Mekong water dispersion: measurements and consequences for the hydrodynamical modeling. J Water Res Environ Eng (Spec Issue Aug 2007):21-28

Howarth RW (1988) Nutrient limitation of net primary production in marine ecosystems. Annu Rev Ecol Syst 19:89-110

Janson S, Wouters J, Bergman B, Carpenter EJ (1999) Host specificity in the Richelia-diatom symbiosis revealed by het $R$ gene sequence analysis. Environ Microbiol 1: 431-438

Jordan TE, Cornwell JC, Boynton WR, Anderson JT (2008) Changes in phosphorus biogeochemistry along an estuarine salinity gradient: the iron conveyer belt. Limnol Oceanogr 53:172-184

Karl DM, Michaels B, Bergman B, Capone DG and others (2002) Dinitrogen fixation in the world's oceans. Biogeochemistry 57:47-98

Kimura M (1983) The neutral theory of molecular evolution. Cambridge University Press, Cambridge, and New York, NY

Kustka A, Carpenter EJ, Sañudo-Wilhelmy SA (2002) Iron and marine nitrogen fixation: progress and future directions. Res Microbiol 153:255-262

Langlois RJ, LaRoche J, Raab PA (2005) Diazotrophic diversity and distribution in the tropical and subtropical Atlantic Ocean. Appl Environ Microbiol 71:7910-7919

Langlois RJ, Hümmer D, LaRoche J (2008) Abundances and distributions of the dominant nifH phylotypes in the Northern Atlantic Ocean. Appl Environ Microbiol 74: 1922-1931

LaRoche J, Breitbarth E (2005) Importance of the diazotrophs as a source of new nitrogen in the ocean. J Sea Res 53: $67-91$

> Le TVH, Nguyen HN, Wolanski E, Tran TC, Haruyama S (2007) The combined impact on the flooding in Vietnam's Mekong River delta of local man-made structures, sea level rise, and dams upstream in the river catchment. Estuar Coast Shelf Sci 71:110-116

> Lovell CR, Piceno YM, Quattro JM, Bagwell CE (2000) Molecular analysis of diazotroph diversity in the rhizosphere of the smooth cordgrass, Spartina alterniflora. Appl Environ Microbiol 66:3814-3822

> Ludwig W, Strunk O, Westram R, Richter L and others (2004) ARB: a software environment for sequence data. Nucleic Acids Res 32:1363-1371

> Marino R, Chan F, Howarth RW, Pace M, Likens GE (2002) Ecological and biogeochemical interactions constrain planktonic nitrogen fixation in estuaries. Ecosystems 5: 0719-0725 doi:

Mills MM, Ridame C, Davey M, LaRoche J, Geider RJ (2004) Iron and phosphorus co-limit nitrogen fixation in the eastern tropical North Atlantic. Nature 429:292-294

> Moisander PH, Hench JL, Kononen K, Paerl HW (2002) Smallscale shear effects on heterocystous cyanobacteria. Limnol Oceanogr 47:108-119

> Moisander PH, Beinart RA, Voss M, Zehr JP (2008) Diversity and abundance of diazotrophic microorganisms in the South China Sea during intermonsoon. ISME J 2: 954-967

- Moisander PH, Beinart RA, Hewson I, White AE and others (2010) Unicellular cyanobacterial distributions broaden the oceanic $\mathrm{N}_{2}$ fixation domain. Science 327:1512-1514

Montoya JP, Voss M, Kähler P, Capone DG (1996) A simple, 
high-precision, high-sensitivity tracer assay for $\mathrm{N}_{2}$ fixation. Appl Environ Microbiol 62:986-993

Montoya JP, Holl CM, Zehr JP, Hansen A, Villareal TA, Capone DG (2004) High rates of $\mathrm{N}_{2}$ fixation by unicellular diazotrophs in the oligotrophic Pacific Ocean. Nature 430: 1027-1031

Mulholland MR (2006) The fate of new production from $\mathrm{N}_{2}$ fixation. Biogeosciences 3:1049-1080

> Mulholland MR, Ohki K, Capone DG (2001) Nutrient controls on nitrogen uptake and metabolism by natural populations and cultures of Trichodesmium (Cyanobacteria). J Phycol 37:1001-1009

Needoba JA, Foster RA, Sakamota C, Zehr JP, Johnson KS (2007) Nitrogen fixation by unicellular diazotrophic cyanobacteria in the temperate oligotrophic North Pacific Ocean. Limnol Oceanogr 54:1317-1327

Perry GD, Duffy PB, Miller NL (1996) An extended data set of river discharges for validation of general circulation models. J Geophys Res 101:21339-21349

Pohlmann T (2006) A meso-scale model of the central and southern North Sea: consequences of an improved resolution. Cont Shelf Res 26:2367-2385

Postgate R (1982) The fundamentals of nitrogen fixation. Cambridge University Press, Cambridge

Sañudo-Wilhelmy SA, Kustka AB, Gobler CJ, Hutchins DA and others (2001) Phosphorus limitation of nitrogen fixation by Trichodesmium in the central Atlantic Ocean. Nature 411:66-69

Scharek R, Latasa M, Karl DM, Bidigare RR (1999a) Temporal variations in diatom abundance and downward vertical flux in the oligotrophic North Pacific gyre. Deep-Sea Res I 46:1051-1075

Scharek R, Tupas LM, Karl DM (1999b) Diatom fluxes to the deep sea in the oligotrophic North Pacific gyre at Station ALOHA. Mar Ecol Prog Ser 182:55-67

Seitzinger SP (1988) Denitrification in freshwater and coastal marine ecosystems: ecological and geochemical significance. Limnol Oceanogr 33:702-724

Short SM, Zehr JP (2005) Quantitative analysis of nifH genes and transcripts from aquatic environments. Meth-

Editorial responsibility: Katherine Richardson,

Copenhagen, Denmark ods Enzymol 397:380-394

Short SM, Jenkins BD, Zehr JP (2004) Spatial and temporal distribution of two diazotrophic bacteria in the Chesapeake Bay. Appl Environ Microbiol 70:2186-2192

Smith SV (1984) Phosphorus versus nitrogen limitation in the marine environment. Limnol Oceanogr 29:1149-1160

Subramaniam A, Yager PL, Carpenter EJ, Mahaffey C and others (2008) Amazon River enhances diazotrophy and carbon sequestration in the tropical North Atlantic Ocean. Proc Natl Acad Sci USA 105:10460-10465

> Villareal TA (1990) Laboratory culture and preliminary characterization of the nitrogen-fixing Rhizosolenia-Richelia symbiosis. PSZN I: Mar Ecol 11:117-132

Villareal TA (1992) Marine nitrogen-fixing diatomcyanobacteria symbioses. In: Carpenter EJ, Capone DG, Rueter JG (eds) Marine pelagic cyanobacteria: Trichodesmium and other diazotrophs, Vol 1. Kluwer, Dordrecht, p 163-174

Voss M, Bombar D, Loick N, Dippner JW (2006) Riverine influence on nitrogen fixation in the upwelling region off Vietnam, South China Sea. Geophys Res Lett 33:022006, doi:10.1029/2005GL025569

Zehr JP, McReynolds LA (1989) Use of degenerate oligonucleotides for amplification of the nifH gene from the marine cyanobacterium Trichodesmium thiebautii. Appl Environ Microbiol 55:2522-2526

Zehr JP, Turner PJ (2001) Nitrogen fixation: nitrogenase genes and gene expression. In: Paul JH (ed) Methods in microbiology Vol 30. Marine Microbiology Academic Press, London, p 271-286

Zehr JP, Mellon MT, Zani S (1998) New nitrogen-fixing microorganisms detected in oligotrophic oceans by amplification of nitrogenase (nifH) genes. Appl Environ Microbiol 64:3444-3450

Zehr JP, Waterbury JB, Turner PJ, Montoya JP and others (2001) Unicellular cyanobacteria fix $\mathrm{N}_{2}$ in the subtropical North Pacific ocean. Nature 412:635-638

> Zehr JP, Jenkins BD, Short SM, Steward GF (2003) Nitrogenase gene diversity and microbial community structure: a cross-system comparison. Environ Microbiol 5:539-554

Submitted: June 28, 2010; Accepted: December 4, 2010 Proofs received from author(s): February 4, 2011 